\title{
Pengaruh Pendidikan Kesehatan terhadap Perilaku Keluarga Penderita TB dalam Upaya Penanggulangan TB Dewasa di Kabupaten ABC Sumatera Barat
}

\author{
Gusneli $^{1 *}$, Rizanda Machmud ${ }^{2}$, Mahathir ${ }^{3}$ \\ ${ }^{1}$ Program Studi Magister Keperawatan Kekhususan Keperawatan Komunitas Fakultas Keperawatan Universitas Andalas \\ ${ }^{2}$ Fakultas Kedokteran Bagian Imu Kesehatan Mayarakat dan Ilmu Kedokteran Komunitas Universitas Andalas \\ ${ }^{3}$ Program Studi Magister Keperawatan Universitas Andalas \\ *Correspondence email: gusnelihendra1980@gmail.com
}

\begin{abstract}
Abstrak. Tuberkulosis (TB) adalah penyakit menular yang menyerang paru dan organ lainnya disebabkan oleh mycobacterium tuberculosis. Tuberkulosis merupakan salah satu penyumbang kematian terbanyak di dunia. Berbagai upaya penanggulangan TB sudah diakukan pemerintah namun belum mencapai hasil maksimal. Dalam upaya penanggulangan TB dibutuhkan peran serta keluarga dalam merawat anggota keluarga yang menderita TB. Penelitian ini bertujuan untuk mengetahui pengaruh pendidikan kesehatan terhadap perilaku keluarga dalam upaya penanggulangan TB di salah satu kabupaten di Sumatera Barat Desain penelitian ini adalah pre test and post test two group design dengan rancangan quasy experimental dengan teknik pengambilan sampel purposive sampling. Sampel penelitian ini adalah keluarga penderita TB dewasa di Kabupaten Dharmasraya yang memenuhi kriteria inklusi sebanyak 30 orang yang terdiri dari kelompok intervensi dan kelompok kontrol. Pengumpulan data dengan menggunakan kuesioner. Hasil penelitian menunjukkan adanya pengaruh pendidikan kesehatan terhadap perilaku keluarga penderita TB dalam upaya penanggulangan TB dewasa meliputi pengetahuan pre test ( $p$ value 0,044$)$ dan post test $(p$ value $0,001)$, sikap pre test ( $p$ value 0,325$)$ dan post test ( $p$ value 0,001$)$, tindakan pre test ( $p$ value 0,348$)$ dan post test ( $p$ value 0,001$)$. Pendidikan kesehatan dapat merubah perilaku keluarga dalam upaya penanggulangan TB. Diharapkan bagi peneliti selanjutnya untuk mengembangkan buku monitoring keluarga penderita TB.
\end{abstract}

Kata kunci: keluarga; pendidikan kesehatan; perilaku; tuberkulosis

\begin{abstract}
Tuberculosis (TB) is an infectious disease that attacks the lungs and other organs caused by mycobacterium tuberculosis. Tuberculosis is one of the biggest contributors to death in the world. Various TB control efforts have been undertaken by the government but have not yet reached maximum results. In efforts to control TB, it takes the role of the family in caring for family members who suffer from TB. This study aims to determine the effect of health education on family behavior in $T B$ prevention efforts in one district in West Sumatra. The sample of this study was the families of adult TB sufferers in Dharmasraya District who met the inclusion criteria of 30 people consisting of intervention and control groups. Data collection using a questionnaire. The results showed that there was an influence of health education on the family behavior of TB patients in efforts to overcome adult TB including pre-test knowledge ( $p$ value 0.044) and post test ( $p$ value 0.001), pre-test attitude ( $p$ value 0.325 ) and post test ( $p$ value 0.001 ), pre test ( $p$ value 0.348) and post test ( $p$ value 0.001). Health education can change family behavior in TB control efforts. It is hoped that further researchers will develop a family monitoring book for TB sufferers.
\end{abstract}

Keywords: family; health education; behavior; tuberculosis

\section{PENDAHALUAN}

Setiap tahun angka kejadian TB terus meningkat. Menurut Word Health Organization (WHO) 1 dari 3 penduduk di dunia menderita TB dan sekitar $10 \%$ diantaranya akan jatuh sakit (WHO, 2018). Indonesia sendiri berada pada peringkat ketiga $(8 \%)$ sebagai penyumbang angka TB di dunia (WHO, 2018). Diperkirakan setiap tahun ada 1.020.000 kasus TB di Indonesia namun baru sekitar 446.732 kasus TB yang dilaporkan dan 2,5\% meninggal. Insiden kasus TB BTA positif sekitar 120 per 100.000 penduduk. Insiden TB dari tahun 2010 hingga 2015 cenderung meningkat meskipun peningkatannya lambat. Pada tahun 2015 angka insiden TB mencapai 130 per 100.000 penduduk meningkat dibandingkan tahun 2010. Kasus tuberkulosis di Indonesia pada tahun 2018 sebanyak 566.623 kasus meningkat dibandingkan tahun 2017 yaitu 446.732 kasus
(Kemenkes RI, 2019).

Penanggulangan TB di Indonesia sudah sejak lama dilakukan oleh pemerintah. Pemerintah sudah mengeluarkan berbagai program penanggulangan TB sesuai dengan pedoman WHO. Salah satu strategi nasional penanggulangan TB di Indonesia adalah dengan DOTS atau Directly Observed Treatment Short-course (Kemenkes RI, 2014). Upaya penanggulangan TB di Indonesia diselenggarakan melalui kegiatan promosi kesehatan, surveilens TB, pengendalian faktor resiko, penemuan dan penanganan kasus $\mathrm{TB}$, pemberian kekebalan dan pemberian obat pencegahan (Kemenkes RI, 2016).

Upaya penanggulangan TB sudah dilakukan oleh Pemerintah pusat sampai daerah. Puskesmas dan jaringannya sebagai lini pertama dalam memberikan pelayanan kesehatan kepada masyarakat sudah 
melakukan berbagai upaya penanggulangan TB melalui kegiatan penjaringan penderita TB, ketuk pintu TB dari rumah ke rumah, program Indonesia sehat melalui pendekatan keluarga. Puskesmas sebagai fasilitas pelayanan kesehatan utama bagi masyarakat sudah melakukan upaya penanggulangan TB melalui promosi, advokasi dan koordinasi, pengendalian faktor, peningkatan kemitraan dan peningkatan kemandirian masyarakat. Walaupun upaya penanggulangan TB sudah banyak dilakukan namun masih belum bisa menekan angka kejadian TB dan penemuan kasus TB belum mencapai hasil yang maksimal.

Upaya penanggulangan TB tidak hanya menjadi tanggungjawab bidang kesehatan namun juga perlu melibatkan keluarga penderita TB yang setiap harinya ada bersama penderita TB. Keluarga mempunyai peran yang sangat penting dalam merawat anggota keluarganya yang menderita TB. Untuk itu keluarga perlu diberikan pendidikan kesehatan supaya perilaku keluarga dapat mendukung upaya penanggulangan TB. Berdasarkan laporan pada bidang P2P Dinas Kesehatan Kabupaten ABC di Sumatera pada triwulan II tahun 2019 didapatkan data penderita TB dewasa 193 kasus dimana posisi pencapaian program $\mathrm{TB}$ untuk CDR berada pada urutan 10 dari 19 Kabupaten Kota di Sumatera Barat. Sedangkan untuk success rate (SR) berada pada urutan 15 dari 19 Kabupaten Kota di Sumatera Barat dengan success rate (SR) tidak di evaluasi $44 \%$ (Dinas Kesehatan Kabupaten Dharmasraya, 2019).

Tenaga kesehatan terutama pengelola program TB dan Perkesmas sudah melakukannya perannya sebagai pendidik dengan memberikan penyuluhan kesehatan tentang TB kepada keluarga penderita TB. Berdasarkan data tersebut peneliti tertarik untuk mengetahui pengaruh pendidikan kesehatan terhadap perilaku keluarga penderita TB dalam upaya penanggulangan TB dewasa di Kabupaten Dharmasraya.Perilaku keluarga meliputi pengetahuan, sikap dan tindakan yang dibuktikan dengan adanya dukungan. Dukungan yang bisa diberikan oleh keluarga dalam bentuk dukungan informasi, dukungan emosional, dukungan penghargaan dan dukungan instrumental.

Penelitian yang dilakukan oleh Puspitasari et. al, (2017) menyatakan bahwa dukungan keluarga sangat dibutuhkan oleh penderita TB dalam menentukan kepatuhan berobat. Dukungan keluarga berupa dukungan instrumental. Hasil penelitian yang dilakukan oleh Latifatul Muna et. al, (2014) menyatakan bahwa penderita TB yang mendapat dukungan sosial yang tinggi dari keluarga memiliki kemungkinan patuh 20 kali penderita TB yang mendapat dukungan sosial yang rendah dari keluarga. Penelitian lain oleh Siregar et. al (2019) menyatakan faktor penting pada penyakit kronis seperti tuberkulosis paru adalah dukungan keluarga bisa berupa dukungan sosial, dukungan instrumen dan dukungan informasi.

Penelitian tentang perilaku penderita TB sangat perlu dilakukan karena perilaku keluarga sangat mempengaruhi dalam upaya penanggulangan TB terutama dalam hal merawat anggota keluarga yang menderita TB. Hal ini sesuai dengan tujuan yang hendak dicapai dalam penelitian ini yaitu mengetahui pengaruh pendidikan kesehatan terhadap perilaku keluarga penderita TB dalam upaya penanggulangan TB dewasa,

\section{METODE}

Desain penelitian ini adalah Pre Test and Post Test Two Group Design dengan rancangan Quasy Experimental yaitu adanya kelompok eksperimen. Untuk penelitian ini analisa bivariat yang digunakan adalah Paired Samples $t$ Test dan independent t test (Sugiyono, 2018). Pengumpulan data dengan menggunakan kuesioner terdiri dari pengetahuan, sikap dan tindakan. Pertanyaan pengetahuan berjumlah 30 item, pernyataan sikap 30 item dan tindakan 15 item.

Sampel pada penelitian ini adalah keluarga penderita TB. Teknik pengambilan sampel adalah purposive sampling. Purposive sampling adalah proses menentukan sampel atas pertimbangan tertentu. Teknik ini diambil karena tidak semua populasi memiliki kriteria yang sudah ditetapkan (Arikunto, S 2014). Jumlah sampel pada penelitian ini adalah 30 orang yang terdiri dari 15 kelompok intervensi dan 15 kelompok kontrol.

\section{HASIL DAN PEMBAHASAN \\ Karakteristik Responden}

Hasil penelitian menunjukkan bahwa hampir separo responden 6 orang $(40,0 \%)$ berada pada kelompok umur 55-65 tahun pada kelompok intervensi dan 35-44 tahun dan 45-54 tahun $(66,6 \%)$ pada kelompok kontrol. Berdasarkan jenis kelamin sebagian besar 11 orang $(73,3 \%)$ pada kelompok intervensi dan pada kelompok kontrol 8 orang $(53,3 \%)$ adalah perempuan. Bila dilihat berdasarkan pendidikan sebagian besar responden kelompok intervensi dan kelompok kontrol berpendidikan rendah. Sedangkan berdasarkan pekerjaan kelompok intervensi 9 orang $(60,0 \%)$ adalah IRT dan kelompok kontrol bekerja sebagai petani $(40,0 \%)$ dan IRT $(40,0 \%)$ (lihat pada tabel 1). 
Gusneli et al, Pengaruh Pendidikan Kesehatan terhadap Perilaku Keluarga Penderita TB dalam Upaya Penanggulangan TB Dewasa di Kabupaten ABC Sumatera Barat

Tabel 1. Karakteristik Responden Berdasarkan umur, Jenis Kelamin, Pendidikan dan Pekerjaan ( $\mathrm{n}=30)$

\begin{tabular}{|c|c|c|c|c|c|}
\hline \multirow{3}{*}{ No } & \multirow{3}{*}{$\begin{array}{l}\text { Karakteristik } \\
\text { Responden }\end{array}$} & \multicolumn{4}{|c|}{ Keluarga Penderita TB } \\
\hline & & \multicolumn{3}{|c|}{ Intervensi } & Kontrol \\
\hline & & $\mathrm{n}$ & $\%$ & $\mathrm{n}$ & $\%$ \\
\hline \multirow[t]{7}{*}{1} & Umur & & & & \\
\hline & $\geq 15-24$ tahun & 0 & 0,0 & 0 & 0,0 \\
\hline & $25-34$ tahun & 1 & 6,7 & 4 & 26,7 \\
\hline & $35-44$ tahun & 3 & 20,0 & 5 & 33,3 \\
\hline & $45-54$ tahun & 5 & 33,3 & 5 & 33,3 \\
\hline & 55-64 tahun & 6 & 20,0 & 1 & 6,7 \\
\hline & Total & 15 & 100,0 & 15 & 100,0 \\
\hline \multirow[t]{4}{*}{2} & Jenis Kelamin & & & & \\
\hline & Laki-laki & 4 & 26,6 & 7 & 46,7 \\
\hline & Perempuan & 11 & 73,4 & 8 & 53,3 \\
\hline & Total & 15 & 100,0 & 15 & 100,0 \\
\hline \multirow[t]{6}{*}{3} & Pendidikan & & & & \\
\hline & SD & 4 & 26.7 & 3 & 20,0 \\
\hline & SMP & 5 & 33,3 & 7 & 46,7 \\
\hline & SMA & 4 & 26,7 & 3 & 20,0 \\
\hline & PT & 2 & 13,3 & 2 & 13,3 \\
\hline & Total & 15 & 100,0 & 15 & 100,0 \\
\hline \multirow[t]{8}{*}{4} & Pekerjaan & & & & \\
\hline & Tani & 1 & 6,7 & 6 & 40,0 \\
\hline & Dagang & 2 & 13,3 & 1 & 6,7 \\
\hline & Swasta & 1 & 6,7 & 1 & 6,7 \\
\hline & PNS, TNI, POLRI & 0 & 0,0 & 1 & 6,7 \\
\hline & Tidak bekerja, IRT & 9 & 60,0 & 6 & 40,0 \\
\hline & Lain-lain & 2 & 13,3 & 0 & 0,0 \\
\hline & Total & 15 & 100,0 & 15 & 100,0 \\
\hline
\end{tabular}

Sumber data: diolah

\section{Analisa Bivariat}

Untuk mengetahui pengaruh pendidikan kesehatan terhadap perilaku keluarga penderita TB kelompok intervensi dan kelompok control meliputi pengetahuan, sikap dan tindakan dapat dilihat pada tabel berikut

Tabel 2. Perbedaan Rata-rata Pengetahuan, Sikap dan Tindakan Responden Sebelum dan Sesudah diberikan Pendidikan Kesehatan $(n=30)$

\begin{tabular}{|c|c|c|c|c|c|c|}
\hline \multirow{2}{*}{ Variabel } & \multicolumn{3}{|c|}{ Intervensi } & \multicolumn{3}{|c|}{ Kontrol } \\
\hline & Mean & SD & p value & Mean & SD & p value \\
\hline \multicolumn{7}{|l|}{ Pengetahuan } \\
\hline Pre-test & 14,73 & 4,31 & \multirow{2}{*}{0.001} & 17,46 & 2,5 & \multirow{2}{*}{0.001} \\
\hline Post-test & 25,26 & 2,73 & & 19,6 & 2,19 & \\
\hline \multicolumn{7}{|l|}{ Sikap } \\
\hline Pre-test & 67,89 & 11,44 & \multirow{2}{*}{0.001} & 71,40 & 7,45 & \multirow{2}{*}{0.001} \\
\hline Post-test & 89,26 & 8,65 & & 73,46 & 6,95 & \\
\hline \multicolumn{7}{|l|}{ Tindakan } \\
\hline Pre-test & 28,13 & 5,74 & \multirow{2}{*}{0.001} & 29,73 & 3,03 & \multirow{2}{*}{0.001} \\
\hline Post-test & 40,6 & 5,03 & & 31,06 & 2,98 & \\
\hline
\end{tabular}

Sumber data: diolah

Tabel 2 menunjukkan adanya peningkatan pengathuan, sikap dan tindakan responden sebelum dan sesudah diberikan pendidikan kesehatan. Dapat dijelaskan bahwa variabel pengetahuan, sikap dan tindakan keluarga penderita TB kelompok intervensi dan kelompok kontrol memilki perbedaan yang signifikan dari nilai pre-test dan post-test dengan $p$ value sebesar 0,001 
Gusneli et al, Pengaruh Pendidikan Kesehatan terhadap Perilaku Keluarga Penderita TB dalam Upaya Penanggulangan TB Dewasa di Kabupaten ABC Sumatera Barat

Tabel 3. Pengaruh Pendidikan Kesehatan Terhadap Pengetahuan, Sikap dan Tindakan Responden Sebelum dan Sesudah diberikan Pendidikan Kesehatan $(n=30)$

\begin{tabular}{|c|c|c|c|c|c|c|c|c|c|}
\hline \multirow{2}{*}{ Variabel } & \multicolumn{4}{|c|}{ Pre-test } & \multicolumn{4}{|c|}{ Post-test } & \multirow[b]{2}{*}{$\Delta$ mean } \\
\hline & Mean & SD & SE & P value & Mean & SD & SE & P value & \\
\hline \multicolumn{10}{|l|}{ Pengetahuan } \\
\hline Intervensi & 14,73 & 4,31 & 1,11 & \multirow{3}{*}{0.044} & 25,26 & 2,73 & 0,70 & \multirow{2}{*}{0.001} & 10,53 \\
\hline Kontrol & 17,46 & 2,55 & 0,66 & & 19,60 & 2,19 & 0,56 & & 2,14 \\
\hline Sikap & & & & & & & & & \\
\hline Intervensi & 67,86 & 11,44 & 2,95 & \multirow{3}{*}{0.325} & 89,26 & 8,65 & 2,23 & \multirow{3}{*}{0.001} & 21,40 \\
\hline Kontrol & 71,40 & 7,45 & 1,92 & & 73,46 & 6,95 & 1,79 & & 2,06 \\
\hline Tindakan & & & & & & & & & \\
\hline Intervensi & 28,13 & 5,74 & 1,48 & \multirow[b]{2}{*}{0.348} & 40,60 & 5,03 & 10,23 & \multirow[b]{2}{*}{0.001} & 12,47 \\
\hline Kontrol & 29,73 & 3,03 & 6,85 & & 31,06 & 2,98 & 6,85 & & 1,33 \\
\hline
\end{tabular}

Sumber data: diolah

Tabel 3 menunjukkan perbedaan nilai yang signifikan pada keluarga penderita TB kelompok intervensi dan kelompok kontrol sebelum dan sesudah diberikan intervensi BEBAS. Data tersebut meliputi beda mean kelompok intervensi sebelum dan sesudah diberikan intervensi BEBAS 10,53 sedangkan pada kelompok kontrol terdapat beda mean sebelum dan sesudah yaitu 2,14. Hasil perubahan hasil uji statistik nilai $\mathrm{p}$ sebelum 0,044 dan sesudah didapatkan nilai $\mathrm{p}$ $=0,001$.

\section{Pemwbahasan}

Pendidikan kesehatan yang diberkan kepada keluarga dilakukan dengan kunjungan rumah langsung dengan 4 sesi dimana masing-masing sesi membahas materi yang berbeda meliputi TB (pengertian TB, penyebab $\mathrm{TB}$, tanda dan gejala $\mathrm{TB}$, cara penularan $\mathrm{TB}$ dan cara pencegahan penularan, pengoabatan $\mathrm{TB}$, efek samping obat dan cara mengatasi efek samping obat, nutrisi penderita $\mathrm{TB}$, kebutuhan istirahat tidur penderita TB, PHBS yang harus dilakukan dalam merawat anggota keluarga dengan TB) dan juga menjelaskan tentang dukungan yang bisa diberikan keluarga meliputi dukungan informasi, penghargaan, emosional dan instrumental. Masing-masing sesi dengan interval waktu 1 minggu.

Pendidikan kesehatan diberikan dengan menggunakan lembar balik dilakukan selama 30-45 menit tiap sesi. Setelah selesai penyampaian materi dilakukan diskusi dengan responden dan kepada responden diberikan leaflet dan stiker tentang TB untuk bisa dibaca kembali oleh responden. Pendidikan kesehatan diberikan secara bertahap dengan pertimbangan tingkat pendidikan, umur dan pekerjaan responden.

Pendidikan kesehatan adalah proses perubahan perilaku secara terencana pada diri individu, kelompok atau masyarakat supaya lebih mandiri dalam mencapai tujuan hidup sehat (Suliha, 2008). Pendidikan kesehatan merupakan proses belajar individu, kelompok dan masyarakat dari tidak tahu menjadi tahu, dari tidak mampu mengatasi masalah kesehatan sendiri menjadi mandiri. Pendidikan kesehatan merupakan suatu usaha atau kegiatan untuk membantu individu, kelompok dan masyarakat dalam meningkatkan kemampuan baik pengetahuan, sikap maupun keterampilan agar tercapai hidup sehat secara optimal (Nasution, 2004).

Pendidikan kesehatan yang diberikan kepada seseorang dengan menggunakan metode atau media yang mendukung dan mudah dipahami dapat memberikan perubahan pada perilaku seseorang. Menurut (Notoadmodjo, 2012) pendidikan kesehatan adalah suatu upaya menyampaikan pesan kesehatan kepada individu, kelompok dan masyarakat supaya memperoleh pengetahuan kesehatan yang lebih baik.

\section{Karakteristik Responden}

Berdasarkan hasil penelitian didapatkan hasil bahwa hampir separo responden 6 orang $(40,0 \%)$ berada pada kelompok umur 55-65 tahun pada kelompok intervensi dan 35-44 tahun dan 45-54 tahun $(66,6 \%)$ pada kelompok kontrol. Berdasarkan jenis kelamin sebagian besar 11 orang $(73,3 \%)$ pada kelompok intervensi dan pada kelompok kontrol 8 orang $(53,3 \%)$ adalah perempuan. Bila dilihat berdasarkan pendidikan sebagian besar responden kelompok intervensi dan kelompok kontrol berpendidikan rendah. Sedangkan berdasarkan pekerjaan kelompok intervensi 9 orang $(60,0 \%)$ adalah IRT dan kelompok kontrol bekerja sebagai petani $(40,0 \%)$ dan IRT $(40,0 \%)$.

Hasil penelitian ini sejalan dengan penelitian yang dilakukan oleh Suarnianti dkk (2019) dimana sebagian besar keluarga penderita TB adalah berusia produktif dan berjenis kelamin perempuan. Hasil penelitian lain menyatakan bahwa sebagian besar pendidikan keluarga penderita TB adalah berpendikan rendah dan bekerja sebagai petani Yermi dkk (2018).

Umur, pendidikan dan pekerjaan merupakan faktor internal yang mempengaruhi pengetahuan seseorang. Sedangkan faktor eksternalnya adalah lingkungan, dan sosial budaya. Sedangkan menurut Green et.al, (1993) tentang teori promosi kesehatan menyatakan bahwa ada beberapa faktor yang dapat mempengaruhi perilaku seseorang yaitu faktor predisposisi yang terdiri dari pengetahuan dan sikap (Notoadmodjo, 2014). 


\section{Perbedaan Rata-rata Pengetahuan, Sikap dan Tindakan Responden Sebelum dan Sesudah diberikan Pendidikan Kesehatan}

Berdasarkan hasil penelitian pada kelompok intervensi didapatkan bahwa $p$ value pada semua variabel adalah 0,001. Dari hasil ini dapat diartikan adanya perbedaan rata-rata pengetahuan, sikap dan tindakan keluarga penderita TB sebelum dan sesudah diberikan pendidikan kesehatan. Penelitian ini sejalan dengan yang dilakukan Rizana dkk (2016) tentang pengetahuan, sikap dan perilaku keluarga dalam pencegahan penularan TB paru di kota Lhokseumawe menunjukkan adanya perbedaan rata-rata antara pre-test dan post-test pada kelompok intervensi dengan $p$ value 0,001 . Penelitian lain yang berbeda dilakukan oleh Freitas et al (2015) yang membandingkan pengetahuan dan sikap keluarga penderita TB. Walaupun sikap kedua keluarga baik namun ada bukti bahwa pengetahuan keluarga penderita TB tentang TB juga dipengaruhi rasa keingintahuan sosial.

Perubahan perilaku keluarga dalam upaya penanggulangan TB sangat diperlukan terutama dalam bentuk dukungan yang diberikan berupa dukungan informasi, penghargaan, instrumental dan emosional. Dukungan emosional yang diberikan keluarga pada penderita TB akan mendorong penderita untuk menjalani pengobatan secara teratur karena dukungan yang diberikan dijadikan sebagai energi penggerak bagi pasien dalam menjalankan suatu program terapi menurut Sardiman (2001 dalam Ulfah, 2013).

Terdapatnya perbedaan rata-rata pengetahuan, sikap dan tindakan keluarga penderita TB disebabkan keluarga sudah mendapatkan pendidikan kesehatan tentang TB dan cara merawat anggota keluarga dengan TB serta dukungan yang diberikan keluarga sehingga keluarga juga merasa termotivasi dalam merawat anggota keluarganya yang menderita TB. Selama ini keluarga tidak terlalu diberikan informasi yang jelas tentang TB dan hanya dilibatkan sebagai PMO.

Keluarga juga merasa termotivasi dengan adanya dukungan informasi yang diberikan berupa pendidikan kesehatan. Setelah diberikan pendidikan kesehatan keluarga penderita TB akan merasakan manfaat dari apa yang mereka dapatkan dan mau melakukan tindakan yang baik sebagai upaya penanggulangan TB.

Pengaruh Pendidikan Kesehatan Terhadap Pengetahuan, Sikap dan Tindakan Responden Sebelum dan Sesudah diberikan Pendidikan Kesehatan

Berdasarkan analisis penelitian didapatkan pendidikan kesehatan mempunyai pengaruh yang bermakna terhadap pengetahuan, sikap dan tindakan keluarga penderita TB dengan nilai $\mathrm{p}$ value 0,001 pada variabel pengetahuan, 0,001 pada variabel sikap dan 0,001 pada variabel tindakan. Hasil ini sejalan dengan penelitian Sumiyati dkk (2018) tentang efektifitas penyuluhan kesehatan terhadap perilaku ibu tentang TB pada anak dimana penyuluhan kesehatan efektif terhadap perilaku ibu di Kabupaten Banyumas dengan $p$ value pengetahuan 0,001 dan $p$ value sikap 0,001 .

Penelitian lain oleh Rizana dkk (2016) tentang pengetahuan, sikap dan perilaku keluarga dalam pencegahan penularan tuberkulosis paru di Kota Lhokseumawe menyatakan bahwa terdapat pengaruh pendidikan kesehatan terhadap peningkatan pengetahuan dimana $p$ value pengetahuan $0,001, p$ value sikap 0,001 dan $p$ value perilaku keluarga dalam pencegahan penularan TB paru 0,001 .

Pendidikan kesehatan atau yang biasa disebut penyuluhan kesehatan adalah proses aktif yang memerlukan adanya interaksi antara yang memberi penyuluhan dengan yang mendengarkan penyuluhan supaya terbangun proses perubahan perilaku yang merupakan perwujudan dari pengetahuan, sikap dan keterampilan dari seseorang yang bisa dilihat dan diamati secara langsung atau tidak langsung oleh orang lain. Pendidikan kesehatan merupakan kegiatan untuk membantu individu, kelompok dan masyarakat dalam meningkatkan kemampuan baik pengetahuan, sikap dan keterampilan untuk mencapai hidup secara optimal (Maulana, 2009).

Metode pendidikan kesehatan yang diberikan kepada keluarga diberikan dengan metode audiovisual dan menggunakan bahasa yang mudah dimengerti dengan tujuan keluarga memahami apa yang disampaikan. Metode kesehatan yang didukung oleh media, pesan dan materi yang disampaikan. Penggunaan media yang menarik seperti penggunaan gambar dapat meningkatkan pemahaman seseorang karena menunjukkan gambar realistis (Nies et. al, 2011).

Pemberian pendidikan kesehatan pada keluarga dapat meningkatkan dukungan terhadap pasien TB paru. Keluarga berfungsi sebagai kolektor dan desiminator informasi yang dapat menekan munculnya suatu stressor karena informasi yang diberikan dapat menyumbangkan aksi sugesti yang khusus pada individu (Friedman et. al, 2003). Pemberian pendidikan kesehatan yang dilakukan dapat meningkatkan pengetahuan dan keterampilan sehingga berdampak pada perilaku penderita dan keluarga terhadap perawatan yang dilakukan pada penderita TB. Serta kepatuhan pasien TB dalam pengobatan dipengaruhi oleh dukungan keluarga (Nur Kholifah dkk, 2012).

Hasil penelitian berbeda yang dilakukan Berkanis dkk (2019) tentang pengaruh dukungan keluarga penderita TB terhadap harga diri penderita TB di Kota Kupang menyatakan bahwa dukungan keluarga mempunyai pengaruh yang signifikan terhadap harga diri penderita TB. Seseorang yang mendapat dukungan keluarga secara emosional akan merasa lega dan diperhatikan, mendapat saran atau kesan yang menyenangkan pada dirinya. 
Pendidikan kesehatan sangat penting diberikan kepada keluarga penderita TB untuk dapat merubah perilakunya. Keluarga merupakan orang terdekat dari penderita TB. Penderita TB sering merasa bosan dengan proses pengobatan, merasa rendah diri, dikucilkan, tidak dihargai dan adanya rasa marah terhadap keadaan. Untuk mencegah terjadinya proses pengobatan tidak teratur dan tidak tuntas, stres dan depresi pada penderita TB dibutuhkan dukungan dari keluarga. Keluarga diharapkan memahami kondisi yang dialami oleh penderita TB. Keluarga penderita TB juga perlu diberikan edukasi tentang TB supaya mereka paham dan mampu merawat keluarga dengan TB. Dalam penanggulangan $\mathrm{TB}$ peran keluarga sangat besar sehingga diharapkan keluarga mampu memberikan dukungan pada anggota keluarga yang menderita TB dalam bentuk dukungan informasi, emosional, penghargaan dan instrumental dimana dukungan tersebut dapat dilihat dari perilaku keluarga penderita TB meliputi pengetahuan, sikap dan tindakan.

\section{SIMPULAN}

1. Umur keluarga penderita $\mathrm{TB}$ di Kabupaten $\mathrm{ABC}$ Sumatera Barat pada kelompok intervensi adalah 5565 tahun dan 35-54 pada kelompok kontrol. Jenis kelamin keluarga penderita TB kelompok intervensi dan kelompok kontrol lebih dari separuh adalah perempuan. Pendidikan keluarga penderita TB kelompok intervensi dan kelompok kontrol adalah berpendidikan rendah. Sedangkan menurut pekerjaan pada kelompok intervensi adalah IRT dan kelompok kontrol adalah petani.

2. Adanya perbedaan rata-rata pengetahuan keluarga penderita TB pre-test kelompok intervensi dan kontrol dengan $p$ value 0,044 dan post-test dengan $p$ value 0,001 . Terdapat perbedaan rata-rata sikap keluarga penderita TB pre-test kelompok intervensi dan kontrol dengan $p$ value 0,325 dan post-test dengan $p$ value 0,001 . Adanya perbedaan rata-rata tindakan keluarga penderita TB pre-test kelompok intervensi dan kontrol dengan $p$ value 0,348 dan posttest dengan $p$ value 0,001 .

3. Adanya pengaruh intervensi BEBAS terhadap pengetahuan, sikap dan tindakan keluarga penderita TB antara kelompok intervensi dan kelompok kontrol sesudah diberikan intervensi BEBAS secara bermakna dengan $p$ value $<0,05$ ( $p$ value 0,001$)$

\section{Saran}

1. Bagi Dinas Kesehatan

a. Puskesmas sebagai pusat pelayanan kesehatan masyarakat yang lebih mengutamakan upaya promotif dan preventif perlu melakukan pendidikan kesehatan secara berkala dan terjadwal terutama dalam penanggulangan TB b. Dalam memberikan pendidikan kesehatan kepada masyarakat termasuk keluarga penderita TB perlu memperhatikan umur, jenis kelamin, pendidikan dan pekerjaan.

c. Untuk mencapai hasil yang diharapkan dari pendidikan kesehatan perlu diperhatikan metode dan media yang digunakan. Gunakan media yang menarik dan bahasa yang mudah dimengerti.

d. Untuk merubah perilaku keluarga penderita TB perlu diberikan edukasi dalam bentuk pendidikan kesehatan meliputi pengertian TB, penyebab TB, tanda dan gejala, cara penularan TB, cara mencegah penularan $\mathrm{TB}$, nutrisi pada penderita TB dan kebutuhan istirahat tidur.

e. Untuk merubah perilaku keluarga penderita TB juga diperlukan adanya edukasi kepada keluarga tentang TB, bagaimana cara merawat anggota keluarga dengan TB serta dukungan yang bisa diberikan keluarga sebagai upaya penaggulangan TB.

2. Bagi Perkembagan Ilmu Keperawatan

Mengembangkan berbagai metode untuk meningkatkan perilaku keluarga penderita TB dalam upaya penanggulangan TB dewasa.

3. Bagi Penelitian Selanjutnya

Untuk penelitian selanjutkan diharapkan dapat mengembangkan buku monitoring keluarga penderita TB.

\section{DAFTAR PUSTAKA}

Arikunto, S. (2014). Prosedur Penelitian. Jakarta: Rineka Cipta.

Berkanis, A. T., \& Meriyanti. (2019). Pengaruh Dukungan Keluarga Penderita Tuberculosis ( $\mathrm{Tb}$ ) Terhadap Harga Diri Penderita Tuberculosis ( Tb ) Di Puskesmas Oebobo Kota Kupang. CHM-K Applied Scientifics Journal, 2, 98-110.

Dinas Kesehatan Kabupaten Dharmasraya. (2019). Laporan TB Semester I Dinas Kesehatan Kabupaten Dharmasraya. Pulau Punjung.

Freitas, I. M. de, Popolin, M. P., Touso, M. M., \& et.al. (2015). Factors associated with knowledge about tuberculosis and attitudes of relatives of patients with the disease in Ribeirão Preto , São Paulo , Brazil, 18(2), 326-340. https://doi.org/10.1590/1980-5497201500020004

Friedman, M.M, Bowden, V. . (2003). Family Nursing: Research, Theory \& Practice (5th ed.). New Jersey: Pearson Education Inc.

Kemenkes RI. (2014). Pedoman Nasional Pengendalian Tuberkulosis. Jakarta.

Kemenkes RI. (2016). Peraturan Menteri Kesehatan Republik Indonesia. Jakarta.

Kemenkes RI. (2019). Profil Kesehatan Indonesia 2018. Jakarta.

Maulana, H. D. J. (2009). Promosi Kesehatan. Jakarta: 
EGC.

Muna, L., \& Soleha, U. (2014). Motivasi dn Dukungan Sosial Keluarga Mempengaruhi Kepatuhan Berobat Pada Pasien TB Paru di Poli Paru BP4 Pamekasan, 4, 172-179.

Nasution, S. K. (2004). Meningkatkan Status Kesehatan Melalui Pendidikan Kesehatan dan Penerapan Pola Hidup Sehat. Universitas Sumatera Utara.

Nies, M. ., \& McEWEN, M. (2011). Community Health Nursing:Promoting the Health Population (5th ed). Retrieved from http://evolve.elsevier.com.

Notoadmodjo, S. (2012). Promosi Kesehatan dan Perilaku Kesehatan (Revisi). Rineka Cipta.

Notoadmodjo, S. (2014). Ilmu Perilaku Kesehatan. Jakarta: Rineka Cipta.

Nur Kholifah, S., Minarti, \& Yumni, H. (2012). MODEL ADAPTIF CONSERVATION (ACM) DALAM MENINGKATKAN DUKUNGAN KELUARGA DAN KEPATUHAN BEROBAT PADA PASIEN TB PARU DI WILAYAH KOTA SURABAYA (Adaptif Conservation (ACM) Model in Increasing Family Support and Compliance Treatment in Patient with Pulonary Tuber. Jurnal Ners, 7.

Pusitasari, Mudigdo, A., \& Adriani, R. B. (2017). Effects of Education, Nutrition Status, Treatment Compliance, Family Income, and Family Support, on the Cure of Tuberculosis in Mojokerto , East Java, 273, 141-153.

Rizana, N., Tahlil, T., \& Mulyadi. (2016). Pengetahuan , Sikap Dan Perilaku Keluarga Dalam Pencegahan Penularan Tuberkulosis Paru Knowledge , Attitudes and Behavior of Family in Prevention Pulmonary Tuberculosis Transmission. Jurnal Ilmu Keperawatan, 4(2).

Siregar, I., Siagian, P., Effendy, E., Kesehatan, D., Utara, T., Tapanuli, K., ... Medan, U. (2019). Dukungan Keluarga meningkatkan Kepatuhan Minum Obat pada Penderita Tuberkulosis Paru di Kabupaten Tapanuli Utara The Relationship of Family Support with Medication Adherence in Patients with Pulmonary, 30(4), 309-312.

Suarnianti, S., \& Angriani, S. (2019). Persepsi dan Sikap Keluarga terhadap Perilaku Keluarga dalam Mencegah Penularan TB Paru. Nursing Inside Community, 2(1), 12-18. https://doi.org/10.35892/nic.v2i1.260

Sugiyono. (2018). Metode Penelitian Kuantitatif (1st ed.). Bandung: Alfabeta.

Suliha. (2008). Pendidikan Kesehatan Dalam Keperawatan. Jakarta: EGC.

Sumiyati, Hastuti, P. (2018). Pengetahuan Dan Sikap Ibu Balita Tentang $\mathrm{Tb}$ Paru. Ejournal Poltekkes Semarang, 14(1), 7-13.

Ulfah, M. (2013). Hubungan Dukungan Keluarga Dengan Kepatuhan Minum Obat Pada Pada
Pasien Tuberkulosis DI Wilayah Kerja Puskesmas Pamulang Kota Tangerang Selatan. Universitas Islam Negeri Syarif Hidayatullah.

WHO. (2018). Global Tuberculosis Report.

Yermi, Ardi, M., Lahming, Tahmir, S., \& Pertiwi, N. (2018). Knowledge and Attitudes with Family Role in Prevention of Pulmonary Tuberculosis in Maros, Indonesia. Journal of Physics: Conference Series, 1028(1). https://doi.org/10.1088/17426596/1028/1/012001 